\title{
Assessment of Macro and Microelement Accumulation Capability of Aquatic Weeds Growing with Gorgon Nut
}

\author{
I.S. Singh ", Dhiraj Kumar ${ }^{2}$, A.K. Thakur ${ }^{1}$, Manoj Kumar, B.R. Jana, S.M. Raut, \\ B.P. Bhatt ${ }^{2}$, S.P. Singh ${ }^{3}$, Pankaj Kumar Yadav ${ }^{4}$ and Anil Kumar ${ }^{4}$ \\ ICAR Research Complex for Eastern Region, Research Centre for Makhana, Darbhanga-846005, Bihar, India \\ ${ }^{I}$ ICAR-National Institute of Natural Fibre Engineering and Technology, Kolkata-700040, West Bengal, India \\ ${ }^{2}$ ICAR Research Complex for Eastern Region, Patna-800014, Bihar, India \\ ${ }^{3}$ Department of Soil Science, Rajendra Agricultural University, Pusa-84812, Bihar, India \\ ${ }^{4}$ Bhola Paswan Shastri Agricultural College, Purnea-854326, Bihar, India
}

\begin{abstract}
Gorgon nut (Euryale ferox Salisb.) is an aquatic plant, and generally grows in ponds or lakes with aquatic weeds and thus faces strong competition for the uptake of nutrients from the growing medium. However, weeds can be used as roughages for animals and for organic compost as weeds remove nutrients from water bodies. Furthermore, their nutrient absorption capacity has not been studied in detail especially when they are growing in association with gorgon nut. In this study, an attempt has been made to assess the food value of Marsilea quadrifolia, Eichhornia cressipes, Ceratophyllum demersum, Ipomoea aquatica and Azolla pinnata, growing in association with gorgon nut. The results showed that Ipomoea aquatic had the highest protein content while $\mathrm{N}$ concentration was highest in Azolla pinnata (3.60 \%). The maximum $\mathrm{P}$ and $\mathrm{K}$ content were found in Ceratophillum demersum and Ipomoea aquatica, respectively. The highest accumulation of heavy metals was observed in the tissues of Marsilea quadrifolia and lowest in Ipomoea aquatica.
\end{abstract}

Key words: Aquatic weeds, macronutrient, micronutrient, soil sediments, water

\section{Introduction}

Weeds grow under varied edaphic conditions of climate throughout the year in the agricultural field as well as in the uncultivated land. They compete with the main crop in the uptake of nutrients. Singh and Singh (1939) reported that many weeds are highly selective in the absorption of certain ions and are rich in major and trace elements. Likewise, aquatic plants also selectively absorb macro and micronutrients from water and soil sediments (Singh 2017).

*Corresponding author: (Email: induciah@rediffmail.com)
The aquatic environments are normally rich in inorganic nutrients as they receive them from water flowing from the nutrient rich agricultural fields and households of densely populated localities. Therefore, it helps the higher plants to grow profusely in the aquatic environments and thus increase the gross productivity through photosynthesis. Decomposition of aquatic plants also add several inorganic nutrients to aquatic environment, through the activities of microbes (Kumar et al.2018)

Aquatic plants are considered as an important component of the aquatic ecosystem not only as food 
source for aquatic invertebrates, but also act as an efficient accumulator of heavy metals (Janauer 2001). Bio-availability and bio-accumulation of essential and non-essential metals in aquatic ecosystems is gaining significance globally. Several of the submerged, emergent and free floating aquatic plants are known to accumulate and bio-concentrate heavy metals producing an internal concentration several folds greater than their surroundings (Chen et al. 2008). Various aquatic macrophytic species show different behaviour regarding their ability to accumulate elements in roots, stems and / or leaves (Jackson 1998). The property of accumulation of elements was found useful in bio-monitoring and amelioration of water bodies (Vajpayee et al. 1995; Whitton and Kelley 1995).

Gorgon nut (Euryale ferox Salisb.) is an aquatic plant with large spiny floating leaves, also known as fox nut or makhana mostly cultivated in ponds (water depth: $0.75 \mathrm{~m}$ to $1.20 \mathrm{~m}$ ) and low lying shallow wetlands having water depth of $0.45 \mathrm{~m}$ to $0.60 \mathrm{~m}$ (Singh 2017). The cultivation of gorgon nut is mainly concentrated in north Bihar and in some part of Assam. Bihar contributes $85 \%$ of the total gorgon nut production from India. The productivity potential of the gorgon nut crop is 2.8 to 3.0 $\mathrm{t} \mathrm{ha}^{-1}$ (Kumar et al. 2014). The yield potential can be increased up to $4.0 \mathrm{t} \mathrm{ha}^{-1}$ but due to heavy infestation of aquatic weeds its potential gets impaired. However, weeds also contribute organic matter and nutrients to the soils on their decomposition and some of them are used as for roughage to animals. The present study highlights the chemical composition of commonly growing weeds associated with Gorgon nut suited to organic compost and fodder.

\section{Materials and Methods}

The weeds E. crassipes, M. quadrifolia, $C$. demersum, I. aquatica and A. pinnata available in the makhana fields were collected prior to the flowering stage from the farm of the ICAR-RCER, Research
Centre for Makhana, Darbhanga. The biomass was calculated on dry weight basis. The weed plants were uprooted from the water column, air-dried and ground through Willey crushing machine to pass through a 2 $\mathrm{mm}$ sieve. The sieved material was stored for chemical analysis.

The numbers of weed plants were counted on per square meter area basis. The organic carbon, total nitrogen $(\mathrm{N})$, phosphorus $(\mathrm{P})$, potassium $(\mathrm{K})$, iron $(\mathrm{Fe})$, manganese $(\mathrm{Mn})$, zinc $(\mathrm{Zn})$ and copper $(\mathrm{Cu})$ plant constituents were estimated according to the procedures outlined by Jackson (1973). The nutrient concentrations in plant samples were expressed on a dry weight basis. Mean nutrient concentrations in the plant material were calculated. Crude protein was estimated, multiplying total nitrogen by a factor of 6.25 .

\section{Results and Discussion}

Population density, biomass yield and protein content of aquatic weeds growing in association with makhana crop

The highest number (132 plants $\mathrm{m}^{-2}$ ) of plants was recorded for $M$. quadrifolia while the lowest was with E. crassipes (Table 1). The number of plants recorded with $C$. demersum and I. aquatica were 5 and 10, respectively. The highest protein content was recorded in the biomass of I. aquatica (25\%) followed by $A$. pinnata $(22.5 \%)$. The other three weed species had almost similar protein content in their vegetative organs. On account of having a large vegetative organ, $E$. crassipes had maximum biomass. The I. aquatica was the second largest contributor of organic matter $(1.30 \mathrm{q}$ $\left.\mathrm{ha}^{-1}\right)$ to the soil whereas the lowest biomass $\left(0.07 \mathrm{q} \mathrm{ha}^{-1}\right)$ was added by $C$. demersum. I. aquatica also contained the highest organic carbon content (45\%) followed by E. crassipes ( $42 \%)$. 
Table 1. Population density, biomass yield and crude protein content of certain aquatic weeds growing in association with makhana crop

\begin{tabular}{lcccc}
\hline \multicolumn{1}{c}{ Aquatic weed species } & No. of plants $/ \mathbf{m}^{2}$ & $\begin{array}{c}\text { Organic carbon } \\
\mathbf{( \% )}\end{array}$ & $\begin{array}{c}\text { Crude protein } \\
\mathbf{( \% ) ~ d . w . )}\end{array}$ & $\begin{array}{c}\text { Standing weed } \\
\text { biomass dry } \\
\text { Weight } \\
\mathbf{( k g ~ h a ~}^{-1} \mathbf{)}\end{array}$ \\
\hline Marsilea quadrifolia & 132 & 36 & 14.06 & 62.00 \\
Eichhornia crassipes & 2 & 42 & 15.35 & 200.00 \\
Ceratophyllum demersum & 5 & 30 & 18.20 & 7.00 \\
Ipomoea aquatica & 10 & 45 & 25.00 & 130.00 \\
Azolla pinnata & - & 29 & 22.50 & 120.00 \\
\hline
\end{tabular}

-Difficult to count

\section{Macronutrient content in aquatic weeds}

The submerged species ( $C$. demersum) had higher content of $\mathrm{N}(2.78 \%)$ compared to floating leaved vascular weed species. A. pinnata was superior than vascular plants for nitrogen content (3.60\%), due to its association with Anabaena azollae further application of Azolla as green manure to wheat (Prasad and Ram 1981) and increased $N$ concentration in wheat crop (Ram and Prasad 1982). On an average, $C$. demersum contained nearly twice the mineral $\mathrm{P}(0.30 \%)$ than the emergent species whereas the lowest content of $\mathrm{P}$ was recorded with $A$. pinnata $(0.08 \%)$. This might be attributed to the fact that $A$. pinnata being a rootless flora do not have any direct support system to absorb nutrients from soil sediments. The similar trend of $\mathrm{P}$ concentration in vegetative tissues of Euryale ferox was reported by Kumar et al. (2018). All the weeds absorb K in higher quantity from the soil solution and it was highest in $E$. crassipes $(2.85 \%)$. The $\mathrm{C}: \mathrm{N}$ ratios varied from 10.80 to 17.70. A critical C:N ratio of 20 for the added organic materials has been suggested by Jensen (1929). According to him, plant residues having a $\mathrm{C}: \mathrm{N}$ ratio above this will cause an initial immobilization of soil nitrogen when added to the soil, whereas below this, net release of inorganic nitrogen will take place. All emergent plants and A. pinnata had C:P ratio more than 225:1. A critical C:P ratio around 200 (Kaila 1949) for the mineralization of soil organic phosphorus has also been described. Thus it can be inferred that these weeds may likely to result in the sustained microbial release of nitrogen, phosphorus and other plant nutrients.

Table 2. Chemical analysis of inorganic elements of aquatic weed species (on oven dry-basis)

\begin{tabular}{lcccccc}
\hline \multicolumn{1}{c}{ Aquatic weed species } & $\begin{array}{c}\text { Organic } \\
\text { carbon } \\
\mathbf{( \% )}\end{array}$ & $\begin{array}{c}\mathbf{N} \\
(\mathbf{\%})\end{array}$ & $\begin{array}{c}\mathbf{P} \\
\mathbf{( \% )}\end{array}$ & $\begin{array}{c}\text { K } \\
\mathbf{( \% )}\end{array}$ & $\mathbf{C : N}$ & $\mathbf{C : P}$ \\
\hline Marsilea quadrifolia & 36 & 2.25 & 0.16 & 1.56 & $16: 1$ & $225: 1$ \\
Eichhorni acrassipes & 42 & 2.40 & 0.13 & 2.85 & $17.5: 1$ & $323: 1$ \\
Ceratophyllum demersum & 30 & 2.78 & 0.30 & 2.52 & $10.8: 1$ & $100: 1$ \\
Ipomoea aquatica & 45 & 2.54 & 0.20 & 2.65 & $17.7: 1$ & $225: 1$ \\
Azolla pinnata & 29 & 3.60 & 0.08 & 0.67 & $8.05: 1$ & $362.5: 1$ \\
\hline
\end{tabular}




\section{Micronutrient content in aquatic weed}

In general, uptake of elements by wetland plants varies among species, and is related to rooting depth and plant life form (Guilizzoni 1991). It was observed that $M$. quadrifolia (2400 $\mathrm{mg} \mathrm{kg}^{-1}$ ) and C. demersum (2405 mg $\mathrm{kg}^{-1}$ ) were equally capable in absorbing Fe from the soil sediment. Singh (2017) reported similar concentration of $\mathrm{Fe}$ in tissues of gorgon nut and water chestnut. Mays and Edwards (2001) opined that submerged and floating-leaved species, which can absorb soluble elements directly from the water into shoots, often have greater accumulation of metals than emergent species. The Mn concentration was found in the order of $M$. quadrifolia (800 $\left.\mathrm{mg} \mathrm{kg}^{-1}\right)$, E. crassipes (1245 $\left.\mathrm{mg} \mathrm{kg}^{-1}\right), C$. demersum (492 $\left.\mathrm{mg} \mathrm{kg}^{-1}\right)$, I. aquatica $\left(700 \mathrm{mg} \mathrm{kg}^{-1}\right.$ ) and $A$. pinnata (360 $\mathrm{mg} \mathrm{kg}^{-1}$ ). Emergent plant species, in general, appeared to contain more concentration of $\mathrm{Mn}$ than the submerged plant (C. demersum). This was in agreement with the findings of Shah and Reddy (2014). A. pinnata had the lowest concentration of $\mathrm{Zn}(40 \mathrm{mg} \mathrm{kg}$ $\left.{ }^{1}\right)$ among the aquatic weeds while the highest concentration of $\mathrm{Zn}$ was recorded in plant tissues of $M$. quadrifolia (195 mg kg-1). Singh (2017) also reported similar findings in Euryale ferox. Maximum accumulation of $\mathrm{Cu}$ was found in shoot system of $M$. quadrifolia (38 $\mathrm{mg} \mathrm{kg}^{-1}$ ) followed by I. aquatica (35 mg $\mathrm{kg}^{-1}$ ) which indicated that this species could be used as phyto-remediant for $\mathrm{Cu}$ contaminated water bodies. Rai and Sinha (2001) and Rai et al. (1996) also reported high accumulation of $\mathrm{Cu}$ in tissues of I. aquatica, Marsilea minuta and Nelumbo nucifera. Similar inferences were also drawn by Sawidis et al.(1995).

Table 3. Micro-nutrient content in aquatic weed species

\begin{tabular}{lcccc}
\hline \multicolumn{1}{c}{ Aquatic weed species } & $\begin{array}{c}\mathbf{F e} \\
(\mathbf{m g ~ k g}\end{array}$ & $\begin{array}{c}\mathbf{M n} \\
\left(\mathbf{m g ~ k g}^{-1}\right)\end{array}$ & $\begin{array}{c}\mathbf{Z n} \\
\left(\mathbf{m g ~ k g}^{-1}\right)\end{array}$ & $\begin{array}{c}\mathbf{C u} \\
\left(\mathbf{m g ~ k g}^{-1}\right)\end{array}$ \\
\hline Marsilea quadrifolia & 2400 & 840 & 195 & 38 \\
Eichhornia crassipes & 2225 & 1245 & 170 & 33 \\
Ceratophyllum demersum & 2405 & 492 & 182 & 28 \\
Ipomoea aquatica & 2300 & 700 & 90 & 35 \\
Azolla pinnata & 550 & 360 & 40 & 32 \\
\hline
\end{tabular}

\section{Conclusion}

Based on chemical composition, the weed species can be used as fodder crop as they were rich in protein content. $C$. demersum was identified as a good source of essential N, P and $\mathrm{K}$. The addition of these weeds is likely to result in the microbial release of nitrogen, phosphorus and other plant nutrients. It could be concluded that $M$. quadrifolia and $C$. demersum have higher capacity to absorb heavy metals from the soil solutions and may be used as phytoremediants.

\section{References}

Chen, G., Zeng, G, Tang, L., Du, C., Jiang, X, Huang, G., Liu, H. and Shen, G. (2008). Cadmium removal from simulated wastewater to biomass byproduct of Lentnusedodes. Bioresource Technology 99, 7034-7040.

Guilizzoni, P. (1991). The role of heavy metals and toxic materials in the physiological ecology of submersed macrophytes. Aquatic Botany 41, 87-109.

Jackson, L.J. (1998). Paradigms of metal accumulation in rooted aquatic vascular plants. The Science of Total Environment 219, 223-231.

Jackson, M.L. (1973). 'Soil Chemical Analysis'. pp. 498. (Prentice Hall of India Pvt. Ltd., New Delhi)

Janauer, G.A. (2001). Is what has been measured of any direct relevance to the success of the macrophyte in its particular environment? Journal of Limnology 60, 33-38. 
Jensen, H.L. (1929.) On the influence of the carbon: nitrogen ratios of organic material on the mineralization of nitrogen. Journal of Agricultural Science 19, 71-82.

Kaila, A. (1949). Biological Application of Phosphorus. Soil Science 68, 279-89.

Kumar, A., Singh, I.S., Thakur, A.K., Choudhary, A.K., Jha, V., Singh, S.P., Prasad, S.S., Yadav, Pankaj. and Kumar, Ramesh (2018). Bioaccumulation of plant nutrients by Euryale ferox (Salisb.) growing in field condition in northern Bihar of North India. International Journal of Current Microbiology and Applied Sciences 6, 12291237.

Kumar, L., Gupta, V.K., Singh, I.S., Bhatt, B.P. and Kumar, D. (2014). Sequential double cropping system of makhana (Euryale ferox Salisb.). International Journal of Agricultural and Statistical Sciences 10, 105-108.

Mays, P.A. and Edwards, G.S. (2001). Comparison of heavy metal accumulation in a natural wetland and constructed wetlands receiving acid mine drainage. Ecological Engineering 16, 487-500.

Prasad, Jagdish and Ram, H. (1981). Use of Azolla in wheat. Seed and Farms 7, 13-14.

Rai, U.N. and Sinha, S. (2001). Distribution of metals in aquatic edible plants: Trapa natans (Roxb.) Makino and Ipomoea aquatic Forsk. Environmental Monitoring and Assessment 70,

Rai, U.N., Sinha, S. and Chandra, P. (1996). Metal monitoring in water resources of Eastern Ghats, Koraput (Orrisa), India by aquatic plants.
Environmental Monitoring and Assessment 43, 125-137.

Ram, H. and Prasad, Jagdish (1982). Comparative study of Azolla and NPK fertilizers on wheat crop. Agricultural Research and Rural Development 5, 43-45

Sawidis, T., Chettri, M.K., Zacharisadis, G.A. and Stratis, J.A. (1995). Heavy metals in aquatic plants and sediments from water systems in Macedonia, Greece ecotox. Environmental Safety 32, 73-80.

Shah, K. and Reddy, M. N. (2014). Accumulation of heavy metals by some aquatic macrophytes in estuarine zone of river Tapi, Surat, Gujarat, India. (IJIRSET-Volume 3).

Singh, B.N. and Singh, L.B. (1939). Relative absorption of nutrients by weeds of arable land. Soil Science 47, 227-230.

Singh, I.S. (2017). Dynamics of nutrients of aquatic crop (Gorgon nut or Makhana) under different systems of cultivation- a review. International Journal of Agricultural Sciences 7, 1309-1316.

Singh, I.S., Thakur, A.K., Kumar, Ashok and Prakash, D. (2017). Makhana ki Tikau Kheti. Kheti 70, 3641.

Vajpayee, P., Rai, U.N., Sinha, S., Tripathi, R.D. and Chandra, P. (1995). Bioremediation of tannery effluent by aquatic macrophytes. Bulletin of Environmental Contamination and Toxicology 55, 546-533.

Whitton, B.A. and Kelley, M.G. (1995). Use of algae and other plants for monitoring rivers. Australian Journal of Ecology 20, 45-56.

Received: June, $2018 \quad$ Accepted: February, 2019 